\section{Darwin's finches worth a mention}

SIR - In his report on the Linnean Society's discussion of evolution in the Galapagos, Peter Boag' said "Darwin . . . omitted any mention of the finches from his Origin of Species". While it is true that Darwin never specified this group either by its vernacular or its Latin name, he did nevertheless mention it several times in the Origin. To see this, it is necessary to remember that thirteen of the twenty-six species of land-bird known to Darwin from the Archipelago were Darwin's finches ${ }^{2}$.

The relevant references in the Origin are few: I quote them in full from the first edition.

Page 48: "Many years ago, when comparing, and seeing others compare, the birds from the separate islands of the Galapagos Archipelago, both one with another, and with those from the American mainland, I was much struck how entirely vague and arbitrary is the distinction between species and varieties."

Page 390: "If we compare, for instance, the number of the endemic land-shells in Madeira, or of the endemic birds in the Galapagos Archipelago, with the number found on any continent, and then compare the area of the islands with that of the continent, we shall see that this is true."

Page 390: "Thus, in the Galapagos Islands, nearly every land-bird, but only two out of the eleven marine birds, are peculiar; and it is obvious that marine birds could arrive at these islands more easily than land-birds."

Page 397: "I will give only one, that of the Galapagos Archipelago, situated under the Equator, between 500 and 600 miles from the shores of South America. Here almost every product of the land and water bears the unmistakeable stamp of the American continent. There are twenty-six land-birds and twenty-five of these are ranked by $\mathrm{Mr}$ Gould as distinct species, supposed to have been created here; yet the close affinity of most of these birds to American species in every character, in their habits, gestures, and the tone of voice, was manifest."

Page 400: "Thus the several islands of the Galapagos Archipelago are tenanted, as I have elsewhere shown, in a quite marvellous manner, by very closely related species; so that the inhabitants of each separate island, though mostly distinct, are related in an incomparably closer degree to each other than to the inhabitants of any other part of the world."

Darwin also has an implied mention of Darwin's finches in the essay of $1844^{3}$ :

"The Galapagos Archipelago is a remarkable instance of this latter fact: here almost every bird, its one mammifer, its reptiles, land and sea shells, and even fish, are almost all peculiar and distinct species, not found in any other quarter of the world: so are the majority of its plants.",

For the list of species of birds in the Archipelago, Darwin no doubt relied on the lists published in 1839 in the Journal ${ }^{2}$, the first version of which is generally known as The Voyage of the Beagle. On page 461, he says, in listing the various bird taxa:

"9th. A group of finches, of which Mr Gould considers there are thirteen species; and these he has distributed into four new sub-genera. These birds are the most singular of any in the Archipelago. They all agree in many points; namely, in a peculiar structure of their bill, short tails, general form, and in their plumage. The females are grey or brown, but the old cocks jet-black. All the species, excepting two, feed in flocks on the ground, and have very similar habits. It is very remarkable that a nearly perfect gradation of structure in this one group can be traced in the form of the beak, from one exceeding in dimensions that of the largest gros-beak to another differing but little from that of a warbler."
In the much revised second edition of The Voyage of the Beagle, in 1845, Darwin illustrates four of the finches, and says: "'Seeing this gradation and diversity of structure in one small, intimately related group of birds, one might really fancy that from an original paucity of birds in this archipelago, one species had been taken and modified for different ends"'

It is at least likely that Darwin, when writing the Origin, which he regarded as an abstract, thought that he had already given sufficient detail about Darwin's finches in The Voyage of the Beagle. As all these quotations show, Darwin was well aware of the importance of this famous group of birds.

\section{Department of Biology,}

Mark Williamson

University of York, UK

1. Boag, P.T. Nature 301, 12 (1983)

2. Darwin, $\mathrm{C}$. in Narrative of the Surveying Voyages of His Majesty's Ships Adventure and Beagle Vol.3 (ed Fitzroy, R.) (Colburn, London, 1839).

3. de Beer, G. (ed.) Evolution by Notural Selection, 175 Cambridge University Press, 1958).

\section{Lethergy derived}

SIR - Exergy (= useful or available energy) is a directed number $=(E . \theta)-$ the "Exergy vector". The directed number $(1.1 / 2 \pi)$ is, as usual, denoted by $i$ where $i^{2}$ $=-1$. Exergy is a complex number with real $(x)$ and imaginary (iy) components. The useful component of exergy is the real $x$-axis $\left(E_{\mathrm{r}}, 0\right)$ component. As imaginary constituents are added the $x$-axis component is reduced. Where only the imaginary component $(E, \pi / 2)$ or (iy) exists, that is, the exergy vector lies along the $y$ or imaginary axis, we define the quality as "lethergy" (sic).

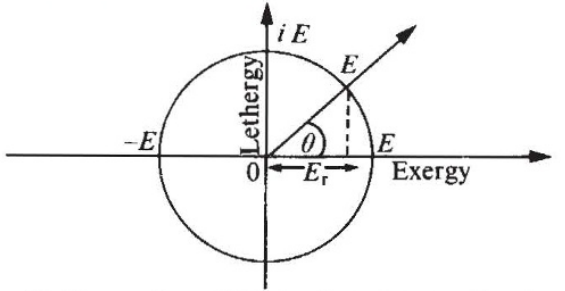

Lethergy is not therefore mere absence of exergy but a positive force leading in the wrong (imaginary) direction. It can, in theological terms, be likened to evil which is not absence of good but a positive malevolent force leading in the wrong direction. In other words, imaginary solutions to the energy equation lead in the wrong direction, reducing the amount of exergy or useful energy available.

(The concept can be generalized in industrial terms with the real axis as industry and the imaginary axis "sloth", giving the industry-sloth diagram for economic analysis.)

The lethergy or (iy) component is a function of the constraints on the energy supply system.

Constraints which increase the lethergy component of the exergy vector can be listed:

(1) Lack of investment

(2) Long engineering lead times

(3) Management inexpertise

(4) Union proliferation and internal strife

(5) Lack of political will to initiate long term strategy

(6) The Environmental lobby

(7) Over-optimism about technological solutions

(8) Raw material shortages

(9) Emotional paralysis - fear of a nuclear accident

(10) Planning delay and impotence

(11) Lack of trained manpower and construction potential

In extreme instances the angle of the exergy vector $(E, \theta)$ can exceed $\pi / 2$ so that the projection onto the $x$-axis becomes negative. For example, the Austrian decision, based on a referendum, not to proceed with or use nuclear power after building the Zwentendorf nuclear station resulted in a negative exergy component.

Where $\theta>\pi / 2$, energy policy can be seen to be having a negative effect.

Some other solutions have a strong "imaginary" or "lethergy" component of the exergy vector. For example:

(i) Solutions with large renewable or solar energy components. (ii) High technology solutions still requiring research and development, for example fusion.

On the other hand North Sea oil and gas and improved technology (for example, fuel-efficient cars) make an important "real" contribution to the exergy vector.

IANFELLS

Department of Chemical Engineering, University of Newcastle Upon Tyne, UK

\section{Dodson's choice}

SIR - The biology of the archaebacteria is currently exciting much interest and among leading contributors to our understanding of this bizarre group of organisms is W. Zillig (see ref.1). Before a new terminology develops to confuse interested onlookers, (otherwise known as "borogroves") ${ }^{2}$ it is perhaps worth recalling that, give or take a consonant or two, Lewis Carroll ${ }^{2}$, with remarkable foresight, seems to have had the matter taped. .

" 'Twas Zillig, and the slithy toves

Did gyre and gimble in the wabe;. . . ."

Surely, "slithy toves"' are none other than archaebacteria and "wabes" their "solfataric water holes" ". How long will it be before "gyre-ases"' and "gimble-ases", the enzymes responsible for their extremely thermophilic metabolism, are described?

\section{University of Sheffield, UK}

D.H. LEWIS

. Fisher, F., Zillig, W., Stetter, K.O. \& Schreiber, G. Nature 301, 511 (1983).

. Carroll, L. Through the Looking Glass (Macmillan, London, 1872). 